\title{
Where urban residents shop for produce
}

\author{
Allison Karpyn, ${ }^{2 *}$ The Food Trust \\ Karyn Tappe, ${ }^{\text {b }}$ Rowan University \\ Amy Hillier, ${ }^{\mathrm{c}}$ University of Pennsylvania \\ Carolyn Cannuscio, ${ }^{\mathrm{d}}$ University of Pennsylvania \\ Julia Koprak, ${ }^{\mathrm{e}}$ The Food Trust \\ Karen Glanz, ${ }^{\mathrm{f}}$ University of Pennsylvania
}

\begin{abstract}
Submitted December 23, 2013 / Revised March 14 and April 23, 2014 / Accepted June 24, 2014 /
Published online September 5, 2014

Citation: Karpyn, A., Tappe, K., Hillier, A., Cannuscio, C., Koprak, J., \& Glanz, K. (2014). Where

urban residents shop for produce. Journal of Agriculture, Food Systems, and Community Development, 4(4), 129-141. http://dx.doi.org/10.5304/jafscd.2014.044.009
\end{abstract}

Copyright (C) 2014 by New Leaf Associates, Inc.

\begin{abstract}
There is limited research documenting the shopping behaviors of urban residents with regard to where they shop for fruits and vegetables. This
\end{abstract}

\footnotetext{
a* Corresponding author: Allison Karpyn, The Food Trust; Philadelphia, Pennsylvania.

Allison is now at the Center for Research in Education and Social Policy, University of Delaware; 201D Willard Hall, 16 West Main Street; Newark, Delaware 19716 USA; +1-302831-6428; karpyn@udel.edu

b Karyn Tappe, Psychology Department, Rowan University; tappe@,rowan.edu

c Amy Hillier, University of Pennsylvania School of Design; ahillier@design.upenn.edu

${ }^{\mathrm{d}}$ Carolyn Cannuscio, Department of Family Medicine and Community Health, Perelman School of Medicine, University of Pennsylvania; cannusci@,wharton.upenn.edu

e Julia Koprak, The Food Trust; jkoprak@,thefoodtrust.org

${ }^{\mathrm{f}}$ Karen Glanz, Perelman School of Medicine and School of Nursing, University of Pennsylvania; kglanz@upenn.edu
}

study sought to: (1) describe characteristics of consumers who shop for produce at supermarkets, alternative fresh food outlets, and farmers' markets; and (2) identify correlates of farmers' market shopping among urban consumers. Participants were recruited from 30 randomly selected residential blocks in West and Southwest Philadelphia, Pennsylvania, to complete a cross-sectional survey. Of 622 residents contacted, 82.6 percent completed a usable survey. Participants were predominantly African American (75.2 percent), single (47 percent), and receiving public assistance (30.1

\section{Disclosures}

This research was supported by Agriculture and Food Research Initiative Grant no. 2010-85215-20659 from the USDA National Institute of Food and Agriculture Human Nutrition and Obesity Program.

The study design was reviewed and approved by the Institutional Review Board (IRB) of the University of Pennsylvania. While the IRB provided a waiver of written consent, each participant was given an information sheet regarding the study. 
percent). About half of the respondents reported shopping at farmers' markets (48.2 percent), produce stores (47.9 percent), and/or fruit and vegetable trucks (48.0 percent percent) for produce. Having vouchers for farmers' markets was significantly associated with shopping at those markets, being younger, and not owning a car. Our analysis begins to bridge the gap in understanding how individual-level differences may influence shopping patterns. Findings suggest that financial incentives to shop at farmers' markets can be meaningful contributors to shopping at these venues and may work to support the narrowing of disparities in access to healthy, affordable food.

\section{Keywords}

farmers' markets, food access, fruit and vegetables, nutrition, produce, supermarket, food incentives, food policy

\section{Introduction and Literature Review}

Fruits and vegetables are important components of a healthy diet and have a protective effect against many chronic diseases (Boeing et al., 2012; Crowe et al., 2011; U.S. Department of Health and Human Services \& U.S. Department of Agriculture, 2005). Further, adequate consumption of fruits and vegetables is beneficial for weight management (Boeing et al., 2012; Weerts \& Amoran, 2011), a particularly important issue given the national rise in obesity. If trends continue on their current trajectories, obesity rates for adults could reach 44 percent in every state and exceed 60 percent in 13 states within the next 20 years (Trust for America's Health \& Robert Wood Johnson Foundation, 2012). Despite the health benefits, there is a substantial deficit in fruit and vegetable intake for most Americans; the USDA recommends that Americans eat 2.5 cups per day, but very few Americans meet these standards (Akmal \& Flint, 2013; Cassady, Jetter, \& Culp, 2007; Franco, Diez Roux, Glass, Caballero, \& Brancati, 2008).

Previous studies point to the connection between the food environment and fruit and vegetable consumption. A 2002 study, for example, found that for each additional supermarket in a predominantly African American census tract, there was a 32 percent increase in fruit and vegetable consumption (Morland, Wing, \& Diez Roux, 2002). More recent studies have considered connections between produce consumption and available local retail in both urban and rural geographies. These studies have found that closer residential proximity to a supermarket or grocery store was associated with increased probability of fruit and vegetable consumption (Dunn, Dean, Johnson, Leidner, \& Sharkey, 2012) and quantity of fruits and vegetable consumed (Powell, Han, \& Chaloupka, 2005; Zenk et al., 2009), especially among disadvantaged urban populations. However, other studies have found more ambiguous relationships between grocery store availability and dietary intake (Boone-Heinonen, Gordon-Larsen, Kiefe, Shikany, Lewis, \& Popkin, 2011). Still others have suggested that the relationship between store availability and consumption is complex (Cannuscio, Tappe, Hillier, Buttenheim, Karpyn, \& Glanz, 2013).

While there are many studies that examine shopping patterns among urban residents (Hillier, Cannuscio, Karpyn, McLaughlin, Chilton, \& Glanz, 2011), research is limited on where Americans, and disadvantaged urban populations in particular, shop for produce. For groceries generally, Americans rely on supermarkets for major stock-up trips, and increasingly depend on supercenters, such as Walmart, for staples (Basker \& Noel, 2009). However, research also shows that in predominantly African American neighborhoods that lack large supermarkets, residents rely more on smallerformat grocery stores; these small stores may serve as a means to increase healthy food access for disadvantaged urban populations (Raja, Ma, \& Yadav, 2008). Other research considers specialty grocery stores, noting that ethnic minorities often shop at these stores for produce varieties that are culturally appropriate (Adekunle, Filson, Sethuratnam, \& Cidro, 2011). At the same time, ethnic minorities demonstrate an unmet demand for produce in their communities (Adekunle, Filson, \& Sethuratnam, 2012).

Farmers' markets are another type of food retail outlet that has become more prominent, especially in the sale of produce. Nationally, the number of farmers' markets has quadrupled to 
over 7,800 in the last two decades (U.S. Department of Agriculture, 2012). A Five a Day Campaign report, conducted by the California Department of Public Health, found that about one-third of low-income African Americans reported that they shopped regularly at farmers' markets for produce, and that those who made weekly produce purchases at the markets were more likely to meet recommended intake for fruit and vegetables (Keihner, Adkins, \& Scruggs,2004). A recent study in North Carolina found that proximity to farmers' markets was associated with lower body mass index (BMI) among youth (Jilcott, Wade, McGuirt, Wu, Lazorick, \& Moore, 2011). In addition, farmers' markets that offer electronic benefit transfer have been demonstrated to increase fruit and vegetable consumption significantly among Supplemental Nutritional Assistance Program (SNAP) beneficiaries (Krokowski, 2014). Other studies on the growth of farmers' markets and shopping frequency document the growth trajectory of these shopping outlets nationally (Oberholtzer, Dimitri, \& Schumacher, 2012; Young, Karpyn, Uy, Wich, \& Glyn, 2011). Prior research, while limited in scope, suggests that farmers' market vouchers are successful at increasing fruit and vegetable purchase and intake (Fair Food Network, 2012; Herman, Harrison, Afifi, \& Jenks, 2008; Oberholtzer et al., 2012).

However, among all retail formats, little is known about what portion of fruit and vegetable dollars go to which type of shopping outlet, and why, or how the dollar is split between fresh, frozen, and other types of purchases across outlet types. In order to begin to bridge this gap in understanding produce shopping habits, the present study seeks to: 1) describe socioeconomic characteristics of consumers who choose to shop at supermarkets, alternative fresh food outlets, or farmers' markets for produce, and 2) identify predictors of farmers' market shopping among urban residents.

\section{Applied Research Methods}

\section{Sample}

The study area included approximately 18 square miles in six contiguous ZIP code areas in West and
Southwest Philadelphia, Pennsylvania (see Figure 1). The population in this section of West and Southwest Philadelphia is 75 percent African American, 15 percent white, 6 percent Asian, and 1 percent Hispanic, and 28 percent of households live in poverty, according to the 2010 U.S. Census. Thirty block segments were randomly selected from all residential blocks in the study area, in proportion to the population within each ZIP code. Attempts were made to contact a member of every household on those blocks. Eligible participants were adults who were the primary food shoppers for their households and who could speak English. Of the 622 residents who were contacted, 82.6 percent $(\mathrm{N}=514)$ completed a survey. One collected survey was not usable because of missing data on key outcome variables, leaving 513 surveys for the analysis. The final sample was 66 percent female and 34 percent male, 73 percent African American and 17 percent white. Participants ages ranged from 18 to 97, with a median age of 45 . Fewer than 3 percent of participants lived in buildings with 10 or more units. Comparison of the survey sample to 2010 block-level U.S. Census data indicates that the survey participants were fairly representative of their blocks and the study area with regard to race and ethnicity, but the survey sample included a higher rate of homeownership than their blocks and study area. Residents who declined to participate in the study were more likely to be male, African American, and older than were residents who chose to complete the survey.

\section{Measures and Data Collection}

A door-to-door survey was conducted during the summer of 2010 for the first phase of a study designed to identify barriers and facilitators to accessing healthful foods and physical activity (Hillier et al., 2011). Trained interviewers administered a 10 to 15 -minute survey to eligible respondents, programmed on HP iPAQ 110 personal digital assistants (PDAs) with Pendragon forms 5.1 software (Pendragon Software Corporation, Buffalo Grove, Illinois). Interviewers first visited blocks to identify the street addresses of all houses that appeared to be occupied in order to develop detailed paper log sheets. During the second visit, the research teams left on the door of each occu- 
pied residence small "door knocker" signs that described the study and provided a telephone number that residents could call with questions. For multi-unit housing, which was rare in the area, interviewers left study information beside mailboxes or on apartment doors when they were able to gain access. During the subsequent visit, the research team knocked on doors to administer the

\section{Figure 1. Food Retail Landscape, West and Southwest Philadelphia, 2013}

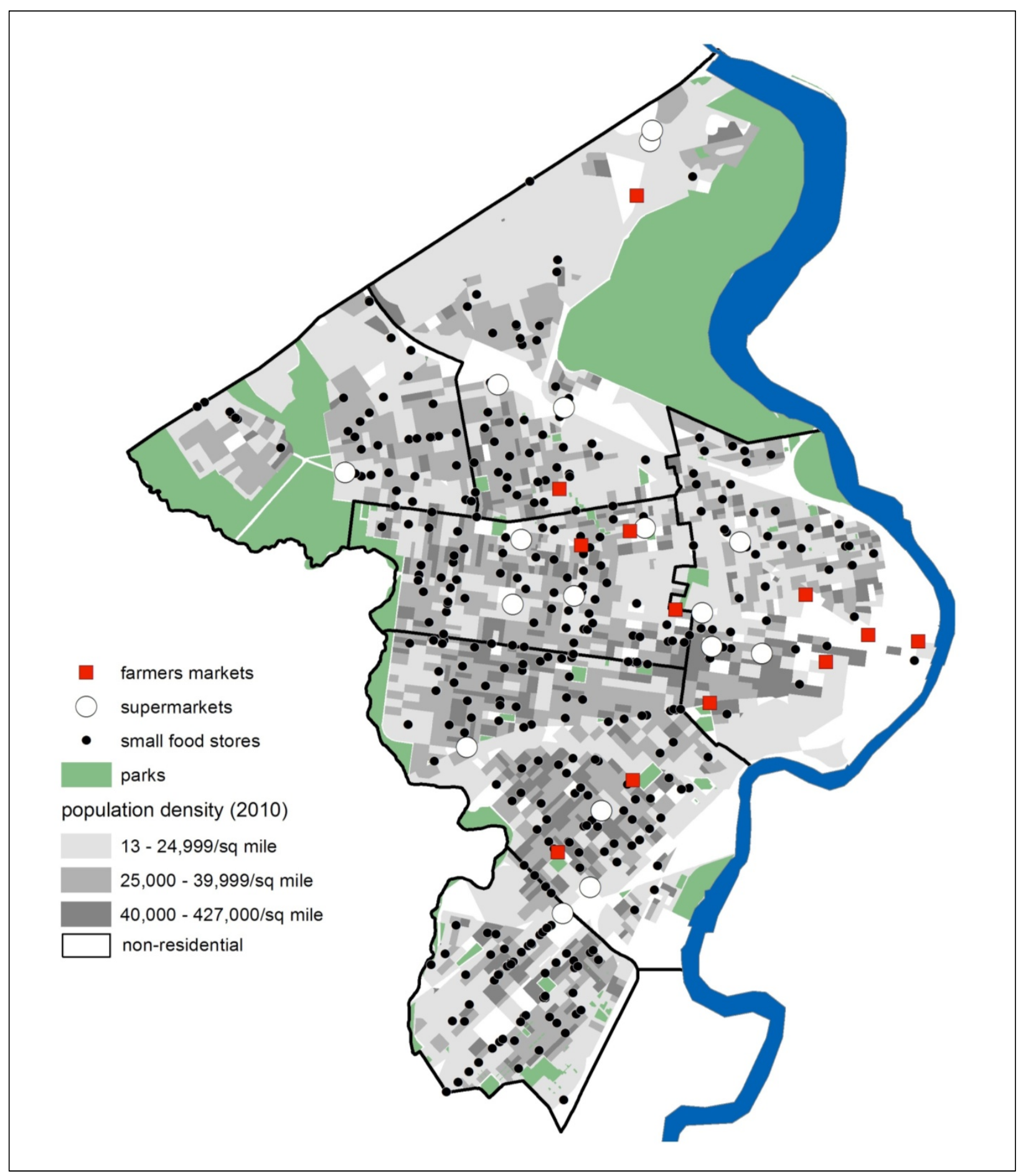


survey. To be eligible to participate in the study, individuals had to live on one of the 30 designated blocks, be at least 18 years of age, and be the primary shopper for their household. Once agreement to participate was obtained, interviewers reviewed and provided an information sheet that outlined the purpose of the study and their rights as study participants. If residents chose not to complete the survey, interviewers recorded their sex, approximate age, race, and reason for refusal, if provided. If no respondent could be reached after three attempts, a copy of the survey was left with a postage-paid return envelope addressed to the study center. Respondents were given a US\$10 gift card for completing the survey. This study was approved by the Institutional Review Board of the University of Pennsylvania.

The survey recorded demographic characteristics including age, race, sex, educational attainment, household income, household size, receipt of public assistance (Women, Infants, and Children (WIC), Food Stamps/Supplemental Nutritional Assistance Program (SNAP), or cash assistance such as Temporary Assistance for Needy Families (TANF)), car ownership, employment status, marital status, and height and weight. Participants reported their height without their shoes on in feet and inches and their weight without shoes in pounds; these data were used to calculate BMI and BMI categories. The survey included questions about food shopping, the presence of healthful items in the household, and the respondent's physical activity behavior. Specifically, the survey asked where residents procured their fruits and vegetables. Respondents were also asked if they received any farmers' market vouchers in the summer through WIC, SNAP, or the Senior Farmers' Market Nutrition Program (SFNMP). Away from home eating was assessed by asking, "In an average week, how many times do you eat your main evening meal away from home (fast food, take out, or sit-down restaurant)?” The presence of fruits and vegetables in the home was assessed by asking respondents if each of seven commonly consumed fruits and vegetables (bananas, apples, oranges, grapes, carrots, tomatoes and dark leafy greens) "were available in your home in the past week" (see Appendix A).

\section{Statistical Analysis}

Responses to the question "Where do you shop for fruits and vegetables?" were categorized into three distinct, mutually exclusive groupings in order to learn more about characteristics of farmers' market shoppers as compared to those who shopped at supermarkets or other specialty stores. Since there were very few respondents who shopped exclusively at farmers' markets, these markets were grouped with other locations. Categories included respondents who shopped at farmers' markets and other locations; those who only shopped at supermarkets, and respondents who reported shopping at "fruit and vegetable specialty stores" but not at farmers' markets. Fruit and vegetable specialty stores included produce stores, fruit and vegetable trucks, and community supported agriculture (CSA) programs that provide weekly containers of a variety of farm-grown products depending on what is in season.

Chi-square analyses were used to provide descriptives about the relationship between demographic characteristics and fruit and vegetable shopping locations. Prediction of farmers' market shopping was analyzed with multivariate logistic regression models, in which demographic characteristics served as the primary predictor variables of interest. Income was not included due to the low response rate for this question. Given many potential predictors, a manual, backwards stepwise regression approach was used, starting with an initial model of all possible predictors, then manually assessing and deleting the least significant term one at a time and comparing the reduced model to the previous model using the likelihood ratio test, which uses the chi-square statistic to evaluate the likelihood that the new model fits the data better or worse than the previous model. If the model fit was significantly worse, the term was returned to the model and the next least significant variable evaluated, until no more variables could be removed without significant reduction in goodness of fit. As a result, nonsignificant covariates that contributed to model strength were retained. The likelihood ratio test for this "final" model relative to the null model (intercept only) is reported. This process also allowed for evaluation of multicollinearity by assessing change in each coefficient and 
standard error with each deletion; no substantial value changes occurred, indicating a lack of multicollinearity problems. Only respondents for whom there were no missing data on the model variables were included in this analysis, yielding a sample of 449 for the full model testing.

All statistical analyses were performed using the SPSS statistical software version 19.0 (IBM, Armonk, New York). The number of respondents included in each analysis varied based on availability of data; Ns are provided in each table of results.

\section{Results}

The mean age of respondents was 46.3 years and 66 percent were female. Mean BMI was 27.9 and 65.1 percent of participants were classified as overweight or obese. Participants were predominantly African American (75.2 percent) and single (47 percent). About one-quarter of participants (28.5 percent) graduated from college and 30.1 percent were classified as receiving public assistance in the form of WIC, SNAP, or cash benefits such as TANF. While 86 percent of respondents replied that they shopped for fruits and vegetables at supermarkets, only 18 percent $(n=94)$ shopped exclusively at supermarkets for produce. About half of respondents reported shopping at farmers' markets (48.2 percent), produce stores (47.9 percent), and fruit and vegetable trucks (48.0 percent). One in five used gardens (their own or other people's) for produce, 10 percent got fresh fruits and vegetables from corner stores and slightly fewer (8.7 percent) shopped at co-ops for produce. CSAs (community supported agriculture programs) were a produce source for fewer than 5 percent of respondents. In order to shop at farmers' markets, 10.7 percent $(n=55)$ of respondents reported receiving vouchers.

To examine further the characteristics of those shopping at farmers' markets in comparison to supermarkets and other alternative produce retail outlets, responses to shopping outlet were further summarized by outlet type: supermarket only, fruit and vegetable specialty stores (including produce stores and fruit and vegetable trucks), or farmers' markets. Appendix B presents chi-square results for demographic variables and locations where residents procured fruits and vegetables. Findings show that race $(p=.02)$, education $(p=.005)$, and household income $(p=.01)$ variables were significantly associated with fruit and vegetable shopping location preferences; receipt of farmers' market vouchers showed a trend towards increased farmers' market shopping over other locations $(p=0.05)$. Whites and "other" races were more likely to report that they shop at farmers' markets, as were respondents with more education and higher incomes.

Across racial subgroups and levels of education, shopping for produce at farmers' markets was more common than shopping only at supermarkets or at fruit and vegetable specialty stores. According to chi-square analyses, white residents were more likely than African American residents to include farmers' markets as a fruit and vegetable shopping destination (60.3 percent versus 44.7 percent). The proportion of respondents who shopped at farmers' markets was higher among more educated respondents, with college graduates shopping at farmers' markets a full 15 percentage points higher than those with less than high school education. Younger residents (59.0 percent) and those who received farmers' market vouchers (64.8 percent versus 47.2 percent, $p=0.05$ ) (see Appendix B) were more like to shop at farmers' markets, as were those with more fruits and vegetables in the household (OR $=1.24, p=0.01$ ) (see Appendix $\mathrm{C}$ ).

Examination of produce store preferences by household income also found that, regardless of income bracket, more residents reported shopping at farmers' markets for produce than at fruit and vegetable specialty stores or solely at supermarkets. Consistent with findings for education, higherincome households reported relatively more frequent shopping at farmers' markets than lowerincome households. Distributing farmers' market vouchers appeared to correlate with an increased use of farmers' markets $(64.8 \%$ versus $47.2 \%$, $p=.05)$. In order to identify correlates of farmers' market shopping among urban residents, a multiple logistic regression model was used (see Appendix C). Receipt of farmers' market vouchers predicted higher likelihood of shopping at farmers' markets, as did younger age and not having access to an 
automobile. Despite the differences observed in chi-square analyses, race $(p=.29)$, receipt of public assistance (a proxy for income) ( $p=.78$ ), and education $(p=.13)$ were not significantly associated with farmers' market shopping after controlling for all other potential confounders.

\section{Discussion}

One approach to increasing consumption of fruits and vegetables is to increase access to such foods by expanding the number of retail outlets that sell produce. Disparities in food store access are well documented, with stores that sell a variety of fruits and vegetables often being farther away and fewer in number in low-income communities and communities of color (Algert, Agrawal, \& Lewis, 2006; Franco et al., 2008; Inagami, Cohen, Finch, \& Asch, 2006; Zenk et al., 2005). Such places have been termed "food deserts" and, according to the USDA, over 29 million Americans live within the designation (Ploeg et al., 2012). Research shows that access impacts dietary behavior, specifically consumption of produce (Bell, Mora, Hagan, Rubin, \& Karpyn, 2013). Federal programs such as the American Reinvestment and Recovery Act of 2009 (US\$650 million), the Patient Protection and Affordable Care Act (US $\$ 100$ million), the National Healthy Food Financing Initiative (US $\$ 500$ million), and state and city grocery financing programs (US $\$ 540$ million) have bolstered fresh food retail efforts to increase access to healthy, affordable food. These programs help to develop and equip grocery stores, small retailers, corner stores, and farmers' markets selling healthy food in an effort to increase access within food desert communities (Lang, Harries, Manon, Tucker, Kim, Ansell, \& Smith, 2013; The Food Trust, PolicyLink, \& The Reinvestment Fund, 2012).

Our analysis begins to bridge the gap in understanding how individual-level differences may influence shopping patterns within resource-rich healthy food environments. First, we looked closely at the question "Where do you get your fruits and vegetables?" Residents reported shopping for produce regularly at a number of types of locations including farmers' markets, food trucks, and produce stores in addition to supermarkets. Differences in shopping location (supermarket only, fruit and vegetable specialty store but not farmers' markets, or farmers' markets plus other stores) were found in unadjusted analysis for race, education, and household income. As such, respondents identifying as African American reported shopping with greater frequency at farmers' markets for produce, as did those with lower household incomes and less education.

We also sought to determine which personal characteristics were significant predictors of farmers' market shopping within our sample. Unlike recent national data which show older adults as most likely to purchase at farm-to-consumer venues (Blanck, Thompson, Nebeling, \& Yaroch, 2011), our findings show that younger residents and those who received farmers' market vouchers are more likely to shop at farmers' markets as are those with more fruits and vegetables in the household. While reasons for this difference were not explored, it raises questions about whether the origin is ideology, concern for health, concern for environmental stewardship, or some other factors. However, consistent with the earlier study, we found that race, income, and education in this community do not differentiate farmers' market shopping preferences in our multivariate analyses. The finding indicates that farmers' markets are not places where only high-income residents or those with more education want to shop, but rather serve as an attractive place for residents of all backgrounds to purchase food. As other research has noted, this broad-based appeal is critical to the sustainability of farmers' markets over the long term (Hicks \& Lambert-Pennington, 2014).

Having vouchers for farmers' markets in part explained produce shopping preferences. Through federal funding, vouchers are distributed annually through the WIC and Senior Farmers' Market Nutrition Programs (SFMNP) to over 2.5 million recipients, and in the case of WIC FMNP, resulted in over US $\$ 14$ million in revenue to farmers in FY2012 (U. S. Department of Agriculture, 2013a, 2013b). In Philadelphia, US $\$ 2$ vouchers called Philly Food Bucks are provided to farmers' market customers, either through every US $\$ 5$ SNAP purchase at the market or through community partners. During the 2012 season, 78\% of vouchers distributed at farmers' markets were redeemed 
(The Food Trust et al., 2012). Furthermore, SNAP sales totaled US\$63,281.71 for the 2012 season, a 12 increase from 2011 SNAP sales (US\$56,496.40); this increase was in part due to increased voucher redemption.

We also found that car owners were less likely to shop at farmers' markets, perhaps because of their greater reliance on supermarket shopping. Earlier studies show that convenience is an important reason customers shop at farmers' markets (Ragland, Lakins, \& Coleman, 2011) but that transportation may be a limiting factor in SFMNP redemption (Southeastern Pennsylvania Resource Conservation Development Council and U. S. Department of Agriculture, 2010); our study may suggest that when farmers' markets are easily accessible by foot, the importance of car ownership is mitigated (see Figure 1).

Ultimately, as many public health organizations advocate for policies that will improve food environments, a better understanding of where consumers shop for produce and other healthy foods will foster targeted efforts to improve supply and demand. Further research should continue to develop a more nuanced understanding of shopper behavior, incentive approaches, and specifically the mechanisms that drive shoppers to purchase foods aligned with the Dietary Recommendations for Americans (HHS \& USDA, 2005). Our findings suggest that efforts to provide financial incentives to shop at farmers' markets are meaningful contributors to shopping at these venues and may help to support narrowing disparities in access to healthy, affordable food. As incentive programs expand and are tested in other venues such as supermarkets, further research is needed to understand how and why such mechanisms work, and which consumers are most likely to be impacted.

\section{References}

Adekunle, B., Filson, G., \& Sethuratnam, S. (2012). Culturally appropriate vegetables and economic development. A contextual analysis. Appetite, 59(1), 148-154. http://dx.doi.org/10.1016/j.appet.2012.04.00

Adekunle, B., Filson, G., Sethuratnam, S., \& Cidro, D. (2011). Acculturation and consumption: Examining the consumption behavior of people of Afro-
Caribbean descent in Canada. Journal of Agriculture, Food Systems and Community Development, 2(1), 297-313. http://dx.doi.org/10.5304/jafscd.2011.021.001

Akmal, S., \& Flint, G. (2013). Endoscopic biopsy of cystic intracerebral tumours. British Journal of Neurosurgery, 27(3), 355-358. http://dx.doi.org/10.3109/02688697.2012.739217

Algert, S., Agrawal, A., \& Lewis, D. (2006). Disparities in access to fresh produce in low-income neigborhoods in Los Angeles. American Journal of Preventive Medicine, 30(5), 365-370. http://dx.doi.org/10.1016/i.amepre.2006.01.009

Basker, E., \& Noel, M. D. (2009). The evolving food chain: Competitive effects of Wal-Mart's entry into the supermarket industry. Journal of Economics and Management Strategy, 18(4), 977-1009. http://dx.doi.org/10.1111/j.1530-9134.2009. 00235.x

Bell, J., Mora, G., Hagan, E., Rubin, V., \& Karpyn., A. (2013). Access to healthy food and why it matters: A review of the research. Oakland, California: PolicyLink and The Food Trust. http://www.policylink.org/sites/default/files/ GROCERYGAP FINAL NOV2013.pdf

Blanck, H. M., Thompson, O. M., Nebeling, L., \& Yaroch, A. L. (2011). Improving fruit and vegetable consumption: Use of farm-to-consumer venues among U.S. adults. Preventing Chronic Disease, 8(2), A49.

Boeing, H., Bechthold, A., Bub, A., Ellinger, S., Haller, D., Kroke, A., . . .\& Watzl, B. (2012). Critical review: Vegetables and fruit in the prevention of chronic diseases. European Journal of Nutrition, 51(6), 637-663. http://dx.doi.org/10.1007/s00394-0120380-y

Boone-Heinonen, J., Gordon-Larsen, P., Kiefe, C., Shikany, J., Lewis, C., \& Popkin, B. (2011). Fast food restaurants and food stores: Longitudinal associations with diet in young to middle-aged adults: The CARDIA Study. Archives of Internal Medicine, 171(13), 1162-1170. http://dx.doi.org/10.1001/archinternmed.2011.283

Cannuscio, C., Tappe, K., Hillier, A., Buttenheim, A., Karpyn, A., \& Glanz, K. (2013). Urban food environments and residents' shopping behaviors. American Journal of Preventive Medicine, 45(5), 606-614. http://dx.doi.org/10.1016/j.amepre.2012.06.021 
Cassady, D., Jetter, K. M., \& Culp, J. (2007). Is price a barrier to eating more fruits and vegetables for lowincome families? Journal of the American Dietetic Association, 107(11), 1909-1915. http://dx.doi.org/10.1016/i.jada.2007.08.015

Crowe, F. L., Roddam, A. W., Key, T. J., Appleby, P. N., Overvad, K., Jakobsen, M. U., . . .European Prospective Investigation into Cancer and Nutrition (EPIC)-Heart Study Collaborators. (2011). Fruit and vegetable intake and mortality from ischaemic heart disease: Results from the European Prospective Investigation into Cancer and Nutrition (EPIC)-Heart study. European Heart Journal, 32(10), 1235-1243.

http://dx.doi.org/10.1093/eurheartj/ehq465

Dunn, R. A., Dean, W. R., Johnson, C. M., Leidner, A., \& Sharkey, J. R. (2012). The effect of distance and cost on fruit and vegetable consumption in rural Texas. Journal of Agricultural and Applied Economics, 44(4), 491-500.

Fair Food Network. (2012). Double Up Food Bucks: 2012 evaluation report. Ann Arbor, Michigan: Fair Food Network. http://www.fairfoodnetwork.org/ sites/default/files/FFN DUFB Evaluation 2012 $\underline{\mathrm{sm} 0 . \mathrm{pdf}}$

Franco, M., Diez Roux, A., Glass, T. A., Caballero, B., \& Brancati, F. L. (2008). Neighborhood characteristics and availability of healthy foods in Baltimore. American Journal of Preventative Medicine, 35(6), 561-567. http://dx.doi.org/10.1016/j.amepre.2008.07.003

Herman, D. R., Harrison, G. G., Afifi, A. A., \& Jenks, E. (2008). Effect of a targeted subsidy on intake of fruits and vegetables among low-income women in the Special Supplemental Nutrition Program for Women, Infants, and Children. American Journal of Public Health, 98(1), 98-105. http://dx.doi.org/10.2105/AJPH.2005.079418

Hicks, K., \& Lambert-Pennington, K. (2014). Evaluating the South Memphis Farmers Market as a strategy to improve access to healthy foods: Lessons from 2011. Journal of Agriculture, Food Systems, and Community Development, 4(2), 45-59. http://dx.doi.org/10.5304/jafscd.2014.042.014

Hillier, A., Cannuscio, C. C., Karpyn, A., McLaughlin, J., Chilton, M., \& Glanz, K. (2011). How far do low- income parents travel to shop for food? Empirical evidence from two urban neighborhoods. Urban Geography, 32(5), 712-729. http://dx.doi.org/10.2747/0272-3638.32.5.712 Inagami, S., Cohen, D. A., Finch, B. K., \& Asch, S. M. (2006). You are where you shop: Grocery store locations, weight, and neighborhoods. American Journal of Preventative Medicine, 31(1), 10-17. http://dx.doi.org/10.1016/j.amepre.2006.03.019

Jilcott, S. B., Wade, S., McGuirt, J. T., Wu, Q., Lazorick, S., \& Moore, J. B. (2011). The association between the food environment and weight status among eastern North Carolina youth. Public Health Nutrition, 14(9), 1610-1617. http://dx.doi.org/10.1017/S1368980011000668

Keihner, A., Adkins, S., \& Scruggs, V. (2004). Shopping habits of African Americans: Relationships with fruit and vegetable consumption. Sacramento, California: California Department of Health Services. http://www.cdph.ca.gov/programs/ cpns/Documents/Network-FV-AA-Shopping.pdf

Krokowski, K. (2014). Evaluating the economic and nutrition benefits and challenges of EBT programs at farmers' markets Journal of Agriculture, Food Systems, and Community Development, 4(2), 37-44. http://dx.doi.org/10.5304/jafscd.2014.042.011

Lang, B., Harries, C., Manon, M., Tucker, J., Kim, E., Ansell, S., \& Smith, P. (2013). Healthy food financing handbook. Philadelphia, Pennsylvania: The Food Trust. http:/ / foodtrust-prod.punkave. net/uploads/media items/hffhandbookfinal. original.pdf

Morland, K., Wing, S., \& Diez Roux, A. (2002). The contextual effect of the local food environment on residents' diets: The atherosclerosis risk in communities study. American Journal of Public Health, 92(11), 1761-1767. http://dx.doi.org/10.2105/AJPH.92.11.1761

Oberholtzer, L., Dimitri, C., \& Schumacher, G. (2012). Linking farmers, healthy foods, and underserved consumers: Exploring the impact of nutrition incentive programs on farmers and farmers' markets. Journal of Agriculture, Food Systems, and Community Development, 2(4), 1-15. http://dx.doi.org/10.5304/jafscd.2012.024.002 
Ploeg, M. V., Breneman, V., Dutko, P., Williams, R., Snyder, S., Dicken, C., \& Kaufman, P. (2012). Access to affordable and nutritious food: Updated estimates of distance to supermarkets using 2010 data (Economic Research Report No. 143). Washington, D.C.: U. S. Department of Agriculture, Economic Research Service. Retrieved from http://www.ers.usda.gov/ ersDownloadHandler.ashx?file $=/$ media $/ 956784 /$ err143.pdf

Powell L. M., Han, E., \& Chaloupka, F. J. (2005). Economic contextual factors, food consumption and obesity among U.S. adolescents. Journal of Nutrition, 140(6), 1175-1180. http://dx.doi.org/10.3945/jn.109.111526

Ragland, E., Lakins, V., \& Coleman, C. (2011). Results of dot survey: USDA Outdoor Farmers' Market, Washington, D.C. Washington, D.C.: U.S. Department of Agriculture, Agriculture Marketing Service. http://www.ams.usda.gov/AMSv1.0/ getfile?dDocName=STELPRDC5093878

Raja, S., Ma, C., \& Yadav, P. (2008). Beyond food deserts: Measuring and mapping racial disparities in neighborhood food environments. Journal of Planning and Education Research, 27(4), 469-482. http://dx.doi.org/10.1177/0739456X08317461

Southeastern Pennsylvania Resource Conservation and Development Council \& United States Department of Agriculture. (2010). Connecting local farmers with USDA Farmers' Market Nutrition Program participants. Perkasie, Pennsylvania: Authors. Retrieved from http://www.ams.usda.gov/ $\underline{\text { AMSv1.0/getfile?dDocName }=\text { STELPRDC508331 }}$ 9\&acct $=$ wdmgeninfo

The Food Trust, PolicyLink, \& The Reinvestment Fund. (2012). A healthy food financing initiative: An innovative approach to improve health and spark economic development. Philadelphia, Pennsylvania: The Food Trust. http://thefoodtrust.org/uploads/ media items/hffi-one-pager.original.pdf

Trust for America's Health \& The Robert Wood Johnson Foundation. (2012). F as in Fat: How obesity threatens America's future 2012. Washington, D.C.: Trust for America's Health. http://healthyamericans.org/report/100/
U.S. Department of Agriculture. (2013a). Senior Farmers' Market Nutrition Program. Washington, D.C.: USDA. Retrieved July 31, 2013, from http://www.fns.usda.gov/wic/SFMNP-FactSheet.pdf

U. S. Department of Agriculture. (2013b). WIC Farmers' Market Nutrition Program. Washington, D.C.: USDA. Retrieved from http://www.fns.usda.gov/ wic/WIC-FMNP-Fact-Sheet.pdf

U.S. Department of Health and Human Services and U.S. Department of Agriculture. (2005). Dietary guidelines for Americans 2005. Washington, DC: HHS \& USDA. Retrieved from http://www.health. gov/dietaryguidelines/dga2005/document/pdf/D GA2005.pdf

Weerts, S. E., \& Amoran, A. (2011). Pass the fruits and vegetables! A community-university-industry partnership promotes weight loss in African American women. Health Promotion Practice, 12(2), 252-260. http://dx.doi.org/10.1177/1524839908330810

Young, C., Karpyn, A., Uy, N., Wich, K., \& Glyn, J. (2011). Farmers' markets in low-income communities: Impact of community environment, food programs and public policy. Community Development, 42(2), 208-220. http://dx.doi.org/10.1080/15575330.2010.551663

Zenk, S. N., Lachance, L., Schulz, A. J., Mentz, G., Kannan, S., \& Ridella, W. (2009). Neighborhood retail food environment and fruit and vegetable intake in a multi-ethnic urban population. American Journal of Health Promotion, 23(4), 255-262. http://dx.doi.org/10.4278/ajhp.071204127

Zenk, S. N., Schulz, A. J., Hollis-Neely, T., Campbell, R. T., Holmes, N., Watkins, G., . . Odoms-Young, A. (2005). Fruit and vegetable intake in African Americans: Income and store characteristics. American Journal of Preventative Medicine, 29(1), 1-9. http://dx.doi.org/10.1016/j.amepre.2005.03.002 
Appendix A. Sample Survey Questions from Healthy Food and Activity Landscapes Household Survey

\section{General Household}

How many people are in your household other than you? We define "household" as anyone who lives in your home and shares most meals or food with you.
a. Adults (over 18):
b. Your own children (under 18):
c. Other children (under 18):

\section{Food Shopping}

What is the name and location of the store where you do most of your food shopping? Please identify the specific address or intersection and town/city if it is outside Philadelphia.

Store Name:

How much do you usually spend when you shop at this store? [All in US\$]

1. Less than $\$ 10$

2. $\$ 10-\$ 25$

3. $\$ 25-\$ 50$

4. $\$ 50-100$

5. More than $\$ 100$

Where do you usually purchase fresh fruit and vegetables? Please select all that apply.
a. corner store
b. supermarket
c. food co-op
d. farmer's market
e. fruit \& vegetable truck
f. your own garden
g. garden of friend/neighbor
h. other
i. you don't buy fresh fruit or vegetables

Do you receive farmer's market coupons in the summer (through WIC or seniors program)?
a. yes
b. no

\section{Demographic Questions}

Where were you born?

a. Philadelphia

b. United States, outside Philadelphia (please specify state or city)

c. another country (please specify country)

Do you currently receive Food Stamps (Supplemental Nutrition Assistance Program or SNAP benefits)?
a. yes
b. no

How would you describe your current employment status?
a. full-time employment (35 hours a week or more year-round)
b. part-time employment
c. unemployed, actively seeking employment
d. not employed, not seeking employment (retired, home-maker, disabled)
e. other (please specify) 


\section{Appendix B. Chi-Square Results for Shopping Locationsa for Fruits and Vegetables by Demographic} Characteristics $(N=514)$

\begin{tabular}{|c|c|c|c|c|c|}
\hline & & Shopping L & ation for Fruits and $\mathrm{Ve}$ & Setables (\%): & \\
\hline & $n$ & $\begin{array}{c}\text { Supermarket only } \\
(n=94) \\
\%\end{array}$ & $\begin{array}{c}\text { Fruit and vegetable } \\
\text { specialty stores }^{\mathrm{b}} \\
\text { (not farmers' }^{\prime} \\
\text { market } \\
\text { participants) } \\
(n=160) \\
\%\end{array}$ & $\begin{array}{c}\text { Farmers' markets } \\
\begin{array}{c}(n=245) \\
\%\end{array}\end{array}$ & Chi-sq, $p=$ \\
\hline Age & & & & & $9.83, p=0.13$ \\
\hline $18-29$ & 100 & 17.0 & 24.0 & 59.0 & \\
\hline $30-44$ & 142 & 23.9 & 28.2 & 47.9 & \\
\hline $45-59$ & 136 & 17.6 & 35.3 & 47.1 & \\
\hline$\overline{60+}$ & 108 & 16.7 & 38.9 & 44.4 & \\
\hline Race & & & & & $11.69, p=0.02$ \\
\hline White & 78 & 16.7 & 23.1 & 60.3 & \\
\hline African American & 360 & 19.2 & 36.1 & 44.7 & \\
\hline Other & 52 & 19.2 & 19.2 & 61.5 & \\
\hline Sex & & & & & $0.97, p=0.62$ \\
\hline Female & 325 & 17.8 & 33.5 & 48.6 & \\
\hline Male & 165 & 20.6 & 29.7 & 49.7 & \\
\hline Education & & & & & $15.06, p=0.005$ \\
\hline High school or less & 187 & 25.7 & 33.7 & 40.6 & \\
\hline Some college & 166 & 17.5 & 27.7 & 54.8 & \\
\hline College graduate & 140 & 11.3 & 33.3 & 55.3 & \\
\hline Household Income/Year & & & & & $8.62, p=0.01$ \\
\hline$\geq 25 \mathrm{~K}$ & 240 & 18.3 & 27.5 & 54.2 & \\
\hline$<25 K$ & 140 & 24.3 & 37.1 & 38.6 & \\
\hline Any Public Assistance & & & & & $0.68, p=0.71$ \\
\hline No & 342 & 18.4 & 33.3 & 48.2 & \\
\hline Yes & 152 & 19.1 & 29.6 & 51.3 & \\
\hline Own a Car & & & & & $0.98, p=0.61$ \\
\hline No & 160 & 18.8 & 29.4 & 51.9 & \\
\hline Yes & 333 & 18.6 & 33.6 & 47.7 & \\
\hline Employment Status & & & & & $2.48, p=0.29$ \\
\hline Not currently working & 177 & 18.6 & 35.6 & 45.8 & \\
\hline Working part-time or full-time & 315 & 19.4 & 28.9 & 51.7 & \\
\hline Receives Food Market Vouchers & & & & & $6.17, p=0.05$ \\
\hline No & 445 & 19.8 & 33.0 & 47.2 & \\
\hline Yes & 54 & 11.1 & 24.1 & 64.8 & \\
\hline
\end{tabular}

a Mutually exclusive categories.

b Includes produce stores, fruit \& vegetable trucks, and community supported agriculture (CSAs). 
Appendix C. Binary Logistic Regression Predicting Farmers' Market Produce Shoppinga

\begin{tabular}{|c|c|c|c|c|c|c|}
\hline \multirow{2}{*}{$\begin{array}{l}\text { Predictor variables } \\
\text { (reference category) }\end{array}$} & \multicolumn{3}{|c|}{ Initial Model ${ }^{b}$} & \multicolumn{3}{|c|}{ Final Modelc } \\
\hline & OR & 95\% C.I & $p$-value & OR & 95\% C.I & $p$-value \\
\hline \multicolumn{7}{|l|}{ Demographics } \\
\hline \multicolumn{7}{|l|}{ Race: } \\
\hline African American & 0.72 & $0.36-1.46$ & .37 & 0.69 & $0.34-1.37$ & .29 \\
\hline White & 1.22 & $0.55-2.72$ & .63 & 1.10 & $0.50-2.43$ & .81 \\
\hline Age & 0.98 & $0.97-1.00$ & .06 & 0.98 & $0.97-1.00$ & .03 \\
\hline Sex (Male) & 0.82 & $0.53-1.26$ & .36 & 0.83 & $0.54-1.28$ & .40 \\
\hline \multicolumn{7}{|l|}{ Marital status: } \\
\hline Single & 0.76 & $0.44-1.33$ & .34 & 0.80 & $0.46-1.39$ & .44 \\
\hline Divorced or widowed & 1.18 & $0.66-2.10$ & .59 & 1.17 & $0.66-2.09$ & .59 \\
\hline Employed & 1.20 & $0.75-1.91$ & .45 & & & \\
\hline \multicolumn{7}{|l|}{ Education level: } \\
\hline Education less than high school & 0.71 & $0.43-1.16$ & .18 & 0.69 & $0.42-1.12$ & .13 \\
\hline College graduate & 0.86 & $0.49-1.51$ & .60 & 0.89 & $0.51-1.53$ & .66 \\
\hline Kids in the home & 0.96 & $0.62-1.49$ & .86 & 1.01 & $0.65-1.56$ & .98 \\
\hline Own automobile & 0.54 & $0.34-0.86$ & .01 & 0.55 & $0.35-0.88$ & .01 \\
\hline $\begin{array}{l}\text { Receiving any form of public } \\
\text { assistance }\end{array}$ & 0.98 & $0.59-1.64$ & .95 & 0.93 & $0.57-1.53$ & .78 \\
\hline Receive farmers' market vouchers & 2.19 & $1.10-4.36$ & .03 & 2.34 & $1.18-4.62$ & .01 \\
\hline \multicolumn{7}{|l|}{ Food sources } \\
\hline \multicolumn{7}{|l|}{ Eating out: } \\
\hline $\begin{array}{l}\text { Eat one meal away from home } \\
\text { each week }\end{array}$ & 1.70 & $1.00-2.86$ & .05 & 1.65 & $0.98-2.77$ & .06 \\
\hline $\begin{array}{l}\text { Eat two or more meals away } \\
\text { from home each week }\end{array}$ & 1.18 & $0.72-1.94$ & .51 & 1.20 & $0.73-1.95$ & .48 \\
\hline $\begin{array}{l}\text { Report high quality fruits and vege- } \\
\text { tables at primary shopping location }\end{array}$ & 1.05 & $0.76-1.45$ & .76 & & & \\
\hline $\begin{array}{l}\text { Number of fruits and vegetables in } \\
\text { home, } 1-7\end{array}$ & 1.24 & $1.10-1.39$ & .00 & 1.24 & $1.11-1.40$ & $<.01$ \\
\hline Constant & 1.15 & & .87 & 1.57 & & .47 \\
\hline
\end{tabular}

a Dependent variable: Binary identification of whether an individual shopped for produce at a farmers' market.

b Initial model statistics: $\mathrm{R}^{2}=.10$ (Cox \& Snell). Model $X^{2}(17)=49.54, p<.001$

c Final model statistics: $\mathrm{R}^{2}=.10$. Model $\mathrm{X}^{2}(15)=49.44, p<.001$ 